Western University Scholarship@Western

Geography Publications

Geography Department

2015

\title{
Towards a Sociogeomorphology of Rivers
}

Peter Ashmore

pashmore@uwo.ca

Follow this and additional works at: https://ir.lib.uwo.ca/geographypub

Part of the Geography Commons

Citation of this paper:

Ashmore, Peter, "Towards a Sociogeomorphology of Rivers" (2015). Geography Publications. 349.

https://ir.lib.uwo.ca/geographypub/349 


\section{Accepted Manuscript}

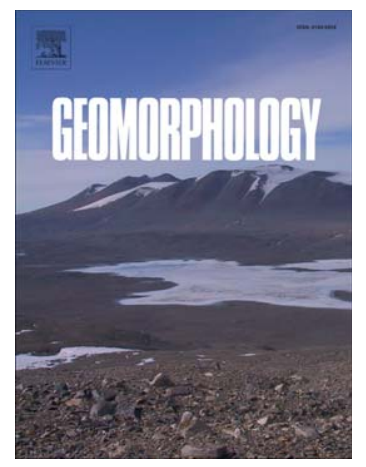

Towards a sociogeomorphology of rivers

Peter Ashmore

PII: $\quad$ S0169-555X(15)00103-8

DOI: doi: $10.1016 /$ j.geomorph.2015.02.020

Reference: $\quad$ GEOMOR 5109

To appear in: $\quad$ Geomorphology

Received date: 28 April 2014

Revised date: 16 December 2014

Accepted date: $\quad 4$ February 2015

Please cite this article as: Ashmore, Peter, Towards a sociogeomorphology of rivers, Geomorphology (2015), doi: 10.1016/j.geomorph.2015.02.020

This is a PDF file of an unedited manuscript that has been accepted for publication. As a service to our customers we are providing this early version of the manuscript. The manuscript will undergo copyediting, typesetting, and review of the resulting proof before it is published in its final form. Please note that during the production process errors may be discovered which could affect the content, and all legal disclaimers that apply to the journal pertain. 


\title{
Towards a sociogeomorphology of rivers
}

\author{
Peter Ashmore, \\ Department of Geography, \\ University of Western Ontario, \\ London, Ontario, Canada, N6A5C2.
}

Email: pashmore@uwo.ca 


\begin{abstract}
While human impacts on rivers and other landforms have long been a component of geomorphic research, little of this work explicitly includes insights into human agency from social science or recognises that in many cases rivers can be considered to be hybrid coproductions or 'socio-natures'. A socio-geomorphic approach proposed here has parallels with some aspects of sociohydrology and can extend and enrich existing geomorphic explanations of the morphology of, for example, urban rivers by explicitly recognising and working with the coevolution of the human and natural systems. Examples from recent literature illustrate ways in which these relationships can be understood and analyzed, showing a range of socio-natural influences in particular contexts that have material consequences for river morphology and recognising that events in the system have many forms. The approach recognises the importance of contingency in time and place together with the role and nature of both local and global knowledge. An important element of this approach is that it provides ways for understanding the nature, position and intention of geomorphic and other scientific interventions as part of the system, for example in the case of river restoration. This also leads to the need for reflexivity by geomorphologists and reconsideration of the nature of geomorphological knowledge by those involved in such work and with respect to sociogeomorphology as a whole.
\end{abstract}


Keywords: rivers, socio-nature, sociogeomorphology, anthropo-geomorphology, urban,river restoration

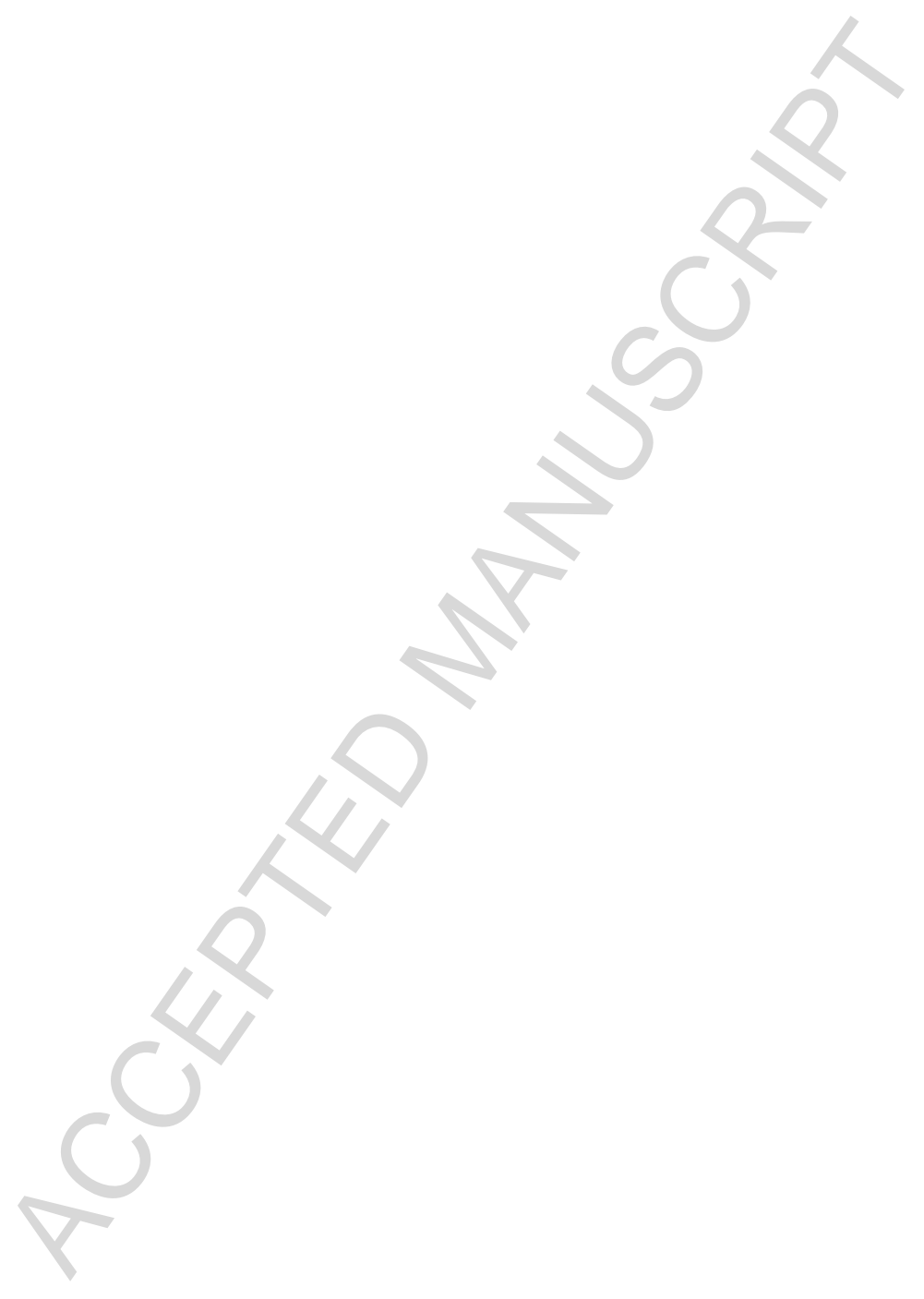




\section{Introduction}

The central concern of geomorphology is with 'natural' processes and landforms and with enquiry and explanations based almost exclusively in the natural sciences. Most textbooks in geomorphology establish this view at the outset and in some cases it is explicit in the title (e.g. Anderson and Anderson, 2010). In most cases the definitions and the scope of geomorphology contain essentially nothing of the role of socio-political processes as an element of contemporary geomorphology and humans are seen almost always as separate from geomorphic systems and impacting the natural system from the outside (Urban 2002; Haff, 2003).

The spatial and temporal frames of geomorphology are wide and in many cases this 'entirely natural' framing may be appropriate. But even in studying contemporary and local landscapes over relatively short time frames, in which these socio-political processes may be relevant, geomorphologists have tended to seek pristine or wild (natural) landscapes and to privilege those as the primary object of study for the discipline (Urban, 2002) and against which human impact is measured. In fluvial geomorphology, highly modified rivers have generally been either avoided as a subject for study or treated as deviating from natural. In the latter case they are seen as an object for restoration to more 'natural' states and on which to practice and impose engineering geomorphology from a technical point of view.

While the primary focus of geomorphology has been on 'natural' processes and landscapes, this is not to say that geomorphology as a discipline has ignored human effects in the landscape; far from it. Textbooks and research articles often describe human impacts on landforms and landscape processes and the role of geomorphology in documenting, managing and mitigating human impacts and hazards. In this sense human impacts on landscapes and the recognition of human-constructed landforms have long had a place in some accounts of, for example, fluvial geomorphology (Gregory, 2006; James and Marcus, 2006). In this context the detailed development of "anthropogenic geomorphology" as documentation, categorization and 
systematization of anthropogenic landforms and impacts of a range of human activities is notable (Szabo et al., 2010). This approach fits into the established scope of geomorphic studies of human-induced changes to landforms and processes with the focus on documenting and quantifying direct and indirect effects of human activities. In this account humans are seen as interfering from the outside and disturbing the natural order, human-constructed landforms are artificial, and humans are seen as disturbing and upsetting natural equilibrium, changing boundary conditions, adding 'unnatural variability' and creating harmful effects. Anthropogeomorphologists then work to measure, document (Graf, 1996) and account for human impact and to conserve, protect and repair landforms from damage (Szabo et al., 2010). There have been several influential and useful analyses of the overall intensity of landform and process modification by human activity illustrating this approach (Hooke, 1994, 1999; Douglas and Lawson, 2001; Haff, 2003, 2010, 2012; Price at al., 2011; Overeem et al., 2013) including analysis of the "anthropic force" (Haff, 2002) in broad framings of landscape dynamics.

An anthropo-geomorphic position in which humans are seen as impacting nature and perturbing natural systems does not allow a complete explanation of the role of humans within these systems, or of the mutual evolution of the 'human' and 'natural' systems, and adheres to a separation of the two. The position is untenable in situations in which the landforms and processes are co-produced by the combined human and 'natural' systems (Urban, 2002). Recognition of this concern is apparent in the oft-repeated calls by geomorphologists to engage more-fully with social sciences to better understand the integration of the physical landscape and the human systems, or to establish a 'cultural' geomorphology (Gregory, 2000, 2006; James and Marcus, 2006; Slaymaker, 2009; NRC 2010; Harden et al., 2014). This arises in part from explicit concern for landscape sustainability, restoration and conservation and the need for codevelopment of a science of human-landscape systems (Harden et al., 2014; Wohl et al., 2014). 
However, there has been little articulation of how this integration might be done and what it would look like as a component of explanations and understanding of landforms and landscapes. Wohl et al. (2014) identify commonalities of conceptualizations among a wide variety of cognate fields that might form a basis for proceeding, which is a useful starting point, but even this kind of integration may be insufficient as an epistemological approach.

In terms of contemporary environmental geography and related fields, many landforms in 'human impacted' and 'restored' landscapes can be seen as hybrid manifestations (coproductions) of nature-culture ( socio-natures) while at the same time raising the question of whether there is a prior or separate "nature" (Eden et al., 2000; Urban, 2002; Castree, 2005; Bakker, 2009; Linton, 2010; Hartmann, 2011; Bouleau, 2013; Di Balldassarre et al., 2013). Adopting a position of hybrid socio-natures of landforms would enable geomorphologists to engage in a more complete explanation of human-impacted and human created landforms bringing the field closer to understanding the why of 'human impact' (Urban, 2002) and a refined ability to model these processes and landscapes at the level of human agency and intention (Ertsen et al., 2014) within a more complete explanatory and predictive framework.

The main goal in this paper is to present examples and show the benefits of taking this position. My use of "socio-geomorphic" is intended to make a distinction from anthropo-geomorphology. Although others (e.g. James and Marcus, 2006) have proposed that anthropo-geomorphology might explicitly include elements of socio-cultural analysis, I use the term here to argue for a distinctive mode of enquiry that explicitly approaches rivers as socio-natures and adopts some of the methods and philosophies related to that idea. My use of the term sociogeomorphology is partly connected with recent developments in socio-hydrology (Hartmann, 2011; Sivapalan et al., 2011; Di Baldassarre et al., 2013; Ertsen et al., 2014; Lane 2014). However, some distinctly different approaches have already emerged in that field (Lane, 2014). One is of socio-hydrology as a "quantitative science of people and water, with the ambition to make predictions of water 
cycle dynamics" with humans as a social force acting on water flows (Sivapalan et al., 2011). This is more analogous to what I have identified as anthropo-geomorphology and it differs substantially from critical and radical conceptions of the water cycle (Linton, 2010; Linton and Budds, 2014; Budds et al., 2014) and socio-hydrology that recognises constructivist accounts of hydrological science (and of science in general) and the ways in which hydrologists' interventions affect outcomes (Lane, 2014) with a goal to explicitly understand human-water systems (Di Baldasarre et al., 2013). This is exemplified by the concept of the hydrosocial cycle in which water circulation is seen as a hybrid biophysical and socio-political set of processes, explicitly contrasting with the asocial and apolitical conception of the hydrological cycle (Budds et al., 2014). Thus this approach to sociohydrology looks at the material flows of water along with the social and political practices and discourses and power relations as an integral part of water flows such that water and society make and remake each other (Linton and Budds, 2014).

My proposition for sociogeomorphology is that geomorphological understanding and explanation can usefully be broadened in some circumstances by adopting the concept of coproduction and of socio-natural systems of landforms, although the exact form of analysis will depend on evolving philosophical positions and directions of development of the idea. This 'more social', approach also recognises alternative ways of framing environmental research and the nature of human agency, and that processes are context-specific with the implication that contingent understanding and explanation are the goals of enquiry rather than generalised quantitative predictions of system dynamics (Budds et al., 2014). It may also connect to more radical framings of geomorphology such as the "ethno-geomorphology" recently proposed by Wilcock et al. (2013). I also propose that this sociogeomorphic approach can be developed within geomorphology and need not necessarily involve inter-disciplinary studies and collaborations with, for example, social science (and see Lane, 2014 on this point). 
Here I introduce elements of this 'more social' approach in the case of river morphology and ways in which explanations of river morphology can be expanded through a more critical view (Lave et al. 2014; Tadaki et al., 2014a) of rivers as co-productions of socio-geomorphic processes (Bouleau, 2013). I do so by first presenting a case of urban river morphology illustrating ways in which 'physical only', anthropo-geomorphic analysis limits understanding of morphological changes. I then move to broaden the discussion using examples from other rivers and aspects of fluvial geomorphology in which analysis of the social aspects of the system lead to expanded understanding. This points the way to future development of the socio-nature of rivers. These examples identify ways in which institutional power, nation-building, political history and ideas, cultural norms and perceptions, socio-natural contingencies, environmental activism, scientific constructs and ambitions, international scientific projects, and the nature of, and motivation for, geomorphic intervention, as well as fluvial processes, can all be seen to play a role in 'explaining' river morphology.

The consequences of this change in perspective include: a move to more place-based, contingent and historical understandings of rivers; the questioning of the role and goal of globalknowledges and predictive explanations; the development of knew paradigmatic questions and propositions; and the recognition that geomorphologists are actors in the socio-geomorphic system whose conceptions and actions are valid and necessary subjects of enquiry.

\section{A case in urban river morphology}

There has been substantial geomorphic analysis of the possible effects of urban development on river morphology (Chin, 2006; Chin et al., 2013). Analyses focus on changes of river morphology as a consequence of the 'impact' of urbanization, primarily through documented or assumed changes in stream-flow hydrology and sediment delivery. There has been very little 
generalization from this assemblage of studies for a variety of reasons (Chin, 2006; James and Marcus, 2006). But even if that were accomplished it is questionable whether a complete understanding of urban river morphology can be achieved by this 'physical only' account that views hydrological change as simply being imposed on the system by some set of urbanization processes, the analysis of which is beyond the norms of geomorphic research.

Highland Creek watershed in the City of Toronto has an area of about $100 \mathrm{~km}^{2}$ draining directly into Lake Ontario (Toronto Region Conservation Authority (TRCA), 1999; Vocal-Ferencevic and Ashmore, 2012). Extensive forest clearance for agriculture occurred in the $18^{\text {th }}$ and $19^{\text {th }}$ centuries as a consequence of European settlement. The dominant agricultural land use was supplanted by urban development between the early 1950 s and the 1980 . Greater than $85 \%$ of the watershed area is now urban land use (much of the remainder is riparian parkland along the main river valleys) and 53\% has impervious surfaces (Toronto Region Conservation Authority (TRCA), 1999; Satgunarajah, 2009; Vocal-Ferencevic and Ashmore, 2012). Especially in the headwaters, surface drainage was extended and modified and many of the headwater channels are rectilinear, lined channels with trapezoidal cross-sections.

One consequence of urbanization has been an abrupt change in the stream-flow regime of the river. A typical annual regime dominated by spring snowmelt freshet and occasional storm events in summer and fall has been transformed into an extremely flashy flow regime with peak flow events at almost any time of year and a comparatively small spring freshet peak. Instantaneous maximum discharges are now 5 or 6 times higher than those of nearby agricultural catchments of similar area and of the pre-urban Highland Creek (TRCA, 1999; O’Neill, 2008; McDonald 2011). 
After severe flooding caused by Hurricane Hazel in 1954, the newly-established Toronto Conservation Authority enacted a policy of clearing any settlement from valley floors in the river systems of Toronto (McLean, 2004). There are similar cases in other river systems in which a single event or set of events set off a train of decision 'events', actions and policies leading eventually to substantial modifications to river morphology and function (e.g. Orsi, 2004). In Highland Creek the removal and banning of any settlement from valley floors might have allowed the rivers the space and time to adjust to streamflow changes following urban development. However, this was quickly circumscribed by construction of traffic bridges for the new arterial grid roads, the use of the valley systems for routing sanitary sewer systems, building construction at the top of unstable valley-side bluffs, and the development of a recreational trail system in the valleys, all of which necessitated the progressive protection of infrastructure, channel straightening and engineered limits to erosion of the river bed and banks. These decisions and actions (of planners, developers, engineers and municipalities) collectively constrained the morphological future of the river and the way in which the river was viewed by these actors.

Highland Creek is almost an ideal inadvertent fluvial geomorphic experiment (Church, 1984) on the impact of human land-use change on channel-forming flows and channel morphology (Chin, 2006) within a 'physical-only' approach. The river experienced a measurable, imposed impact (large increase in channel-forming discharge) caused by human activity. The the consequences for channel morphology can be measured, predicted and compared to theory and to empiricallyderived predictions of river channel adjustment. Deviation of the response from predictions can be accounted for by uncertainty in the relevant independent variables and predictive equations, and precision in observed channel changes (McDonald, 2011). However, Highland Creek was subject to substantial intervention in some reaches in the form of channel engineering. In these cases the standard channel regime formulas yield inconsistent results and a full explanation of response depends on knowing the intention, available knowledge and typical design practice of 
the engineers and their role in the decision-making system. In fact, in many cases a traditional geomorphic view might be that the river is so extensively engineered as to be of no inherent geomorphic interest - essentially the notion that ' the engineers did it' is sufficient and the river then largely disappears from geomorphic view. In neither the engineered nor the 'physical only' analysis is it the norm in geomorphology to think about the problem in a larger context and explicitly engage with those larger circumstances. For example, the land-use and land-use policy changes and interactions against which this geomorphic story played out had a significant effect in determining the future of the river, as did conceptions of, and technical interventions in, modifying the river and protecting infrastructure. These are relevant to a full understanding of the river morphology but are seldom analyzed as part of geomorphological explanation.

The Highland Creek story does not end here. In August 2005 an intense rainstorm affected the headwaters of Highland Creek, with peak instantaneous flows well in excess of the historic maxima. There was extensive channel change and one instance of a major meander cut-off causing the breakage of a sanitary sewer pipe. Similarly to Hurricane Hazel in 1954, this event initiated a phase of extensive re-thinking of the river and its valley and re-construction of several kilometers of one of the main channels. At this point it becomes not only limiting, but actually impossible, to explain the river morphology using a strictly 'physical-only' view. A major and intriguing factor in the need for this shift to a socio-geomorphic view at this stage is that there was greater and more direct intervention by various public, private sector and community actors, as well as the application of fluvial geomorphic principles in analysis and design of the 'new' Highland Creek. Importantly for geomorphological explanation, geomorphic consultants were among those designing, in detail, realignments and the future morphology and function of Highland Creek. Consequently, as is increasingly the case in many such projects, the status, role and position of geomorphic knowledge and expertise needs to be understood in explaining the new morphology (see below). The re-constructed channel has only superficial similarity to the pre-flood river and is radically different from the pre-urban river. At the same time it has set the 
trajectory for the future morphology and dynamics of Highland Creek. There are clear, immediate reasons for these design decisions including protection of infrastructure, design of ecological function, and constraints of the physical setting and compromises around various considerations as well as competing goals and interests of various agencies and people in the process. Seldom is this examined from the point of view of socio-natural explanations of river form and function; what actually happens to result in particular material morphological outcomes for the river and what explanations and theory support this?

The story of Highland Creek helps to see the advantages of a more integrated socio-geomorphic approach in which human agency and intention are tackled explicitly and in which the morphology is explained through the co-evolution of the social and natural systems. This is not new to fields such as geography (e.g. Bakker (2009), Linton and Budds (2013)), or environmental studies, environmental history and ecology, and it has developed rapidly in hydrology in recent years (Linton, 2008; Hartmann, 2011; Di Balldassarre et al., 2013; Ertsen et al., 2014; Lane, 2014). Consequently there are already well-developed ideas, philosophies and methods for thinking about this approach that might be applied to 'doing' sociogeomorphology. In the remainder of the paper I identify some examples of the ways in which a social processes and a socio-geomorphic approach maybe expand understanding of river morphology, especially in urban and 'restored' rivers and argue that such thinking may be more broadly useful given the extent and duration of 'human impact' on rivers globally. I also propose that this is properly a topic for geomorphic enquiry alone, although inter-disciplinary collaboration may be beneficial.

\section{Culture, history and socio-politics in river morphology}

One facet of a socio-geomorphic approach to river morphology is to seek understanding of the ways in which social processes have direct and indirect outcomes for river morphology and the 
ways in which river systems interact with these human systems, with consequences for both. Urban (2002) argued that the 'impacted' landscape has physical characteristics but at the same time contains material, physical effects of types of behaviour determined to be appropriate for a given community. In this way the physical attributes of the landscape depend partly on local socio-cultural dynamics. In the case of the headwater streams of the Embarrass River, Illinois (Urban, 2002), the contemporary fluvial system was strongly influenced by initial perceptions of the original wetland landscape, and changes from direct human action. The extant channel straightening can be explained solely as a pragmatic and efficient approach to land drainage. Urban (2002) goes further by making the case that the orderly, ditched landscape carries significant meaning for the landowners which is in part related to the collective farming aesthetic that values orderly, straight ditches. Thus the rectilinear channel system reflects sociocultural norms as much as the utility of the drainage system. Kondolf (2006) has also argued that a larger cultural and landscape aesthetic is at play in the imposition of stable meandering river forms in many instances of river restoration design.

The legislative and political-economic influences on river morphology and design are also significant and apparent in many ways and at different scales. For example, the transformation of some large river systems in the U.S. into flood control channels has had clear and extensive effects on river morphology and function (O'Neill, 2006). The reasons lie partly in politics and the political history and the role of rivers in nation building and federalism (O'Neill, 2006). In the U.S. the Federal Government has a responsibility for river design inherited ultimately from local and regional lobbying for the need to undertake local flood control in the national interest. The U.S. Army Corps of Engineers became the primary enactors of flood control schemes through political processes which expanded their original (navigation) mandate (O'Neill, 2006). Large scale flood control schemes have the effect of designing rivers in particular ways as the outcome of these political negotiations and as a consequence of particular approaches to river control at particular times and places. This leads directly to transformation of the morphology 
and of the role and meanings of rivers. In this way river control and design can be seen as part of the larger project of state building and justified as a national good (O’Neill, 2006). This also raises the important effect of historical (mainly political) contingency; rivers could have turned out differently but alternatives did not develop or were not politically supported. In the U.S. case, this can be traced in part to the detailed political history of the Federal Flood Control Bill in 1935 (O’Neill, 2006). In this sense “Government made the rivers” (O’Neill, 2006) and it is possible to show in detail how this happened. In recent years the rise of river activism has tried to re-imagine rivers (O’Neill, 2006). The origins of these forces are different and yet also, to some extent locally derived, and politics is still part of the explanation of fluvial outcomes. But historical legacies are still at work and these environmentally motivated projects are constrained by historical actions and fluvial legacies (O’Neill, 2006, Winiwarter et al., 2013).

Similar nation-building agendas and river control ideas are at the heart of the development, and consequent morphology, of the Rhône River in France in the $2^{\text {th }}$ century (Pritchard, 2011). One could argue also that at multi-national scales the European Union Water Framework Directive, for example, is having, and will have, similar large-scale effects on the fluvial landscape (Eden et al., 2000). This type of large scale scientifically-driven agenda and its universal knowledge claims are susceptible to analysis in the same way as the IPCC and its role in defining climate, climate change, climate futures and mitigation have been (Hulme, 2008). This may be a fruitful way of understanding and critically explaining fluvial landscape characteristics that emerge from broad policy initiatives and related international scientific projects. The role of large scale government initiatives' legislation and national culture in re-envisioning of rivers is also evident in river engineering and restoration in Japan (Waley and Åberg, 2011).

The effects of historical and environmental history and contingency are conspicuously manifest in the Los Angeles River, famous for having been engineered into dramatic and iconic concrete flood control channels in the mid-20 ${ }^{\text {th }}$ century. The details of the development of the Los 
Angeles River, the political history, the nature of the engineering of the river system and its eventual conversion to a system of concrete flood control channels has been well-described (Gumprecht,1999; Orsi,2004) as have the related complexities of river system and hazards management (Cooke, 1984). The Los Angeles River looks as it does for a complex set of reasons and histories, apart from the actual engineering practices and principles used to design the channel system. Prominent among these is the importance of historical contingency in both the social and natural realms, and their interaction. This form of contingency has significance for the types and relevance of generalities that might emerge from analysis of this type of system. An example is the occurrence of natural flood events at particular points in political history, economic development, and evolution of socio-political power structures (Orsi, 2004). In the case of the Los Angeles River the exact path and history of channel changes, the move towards particular types of projects and designs relative to alternatives, and the eventual engineering of the river channels all have complex histories unique to the particular case (Gumprecht, 1999; Orsi, 2004; Wolch, 2007). Again, the river need not have turned out the way it has but it is important to understand why it has both for its own sake and because it sets the path for future changes to the river. Orsi (2004) argues that the city and the river system in particular is a complexly organised, highly contingent and tightly coupled "ecosystem" patterned around historical events, agents and structures. Structures such as political arrangements both generate and are generated by historical events including physical floods (which stimulated funding of the flood control channels). But events are not just physical floods. In socio-natural systems events may be election outcomes, founding of environmental organizations, shifting responsibilities between agencies or levels of government or many other such things, some of which are direct responses to the physical events and so modify future events. Events may also be "staged" (Lane, 2014) i.e. deliberate interventions such as public meetings and planning groups designed to analyze and enact a particular plan for the river. Floods are not purely physical, they are "ordered events" (Orsi, 2004) that themselves grow out of intricate 
relationships and historical changes in interactions between nature and human choice about how to structure society and community, and the jurisdictional and power relations locally (see also The Center for Governmental Studies, 2002) . These events have specific material consequences for the morphology, characteristics and functioning of the river.

The river morphology is also a consequence of the ways in which the river was perceived by the community at large (e.g. as hazardous and threatening) (Orsi, 2004; Gandy, 2006; Wolch, 2007) and the ways in which those perceptions change over time. In relation to perceived hazards, action on geomorphic and hydrologic hazards is bound up in complex jurisdictional conflicts, societal philosophies of individual and communal action, the politics of who is affected and the hierarchy of perceived environmental problems (Cooke, 1984). All of this eventually affects the nature of any structural or other solutions within the existing hydro-geomorphic system and therefore the characteristics and geomorphic functioning of that system.

Following this theme, the contemporary Los Angeles River has also been seen as a consequence of the particular form of environmental and local governance, and community attitudes towards the river (Desfor and Kiel, 2000). In contrasting the Don River in Toronto with the Los Angeles River, Desfor and Kiel (2000) point out the differing roles of the rivers in the community and collective imagination. While the Don was a genteel, bucolic, home- away-from-home for early British settlers and part of the liveable city, the Los Angeles River was seen generally as part of a treacherous landscape and a threat to be dealt with (Orsi, 2004). The rivers look different partly because societal relations with nature are not all the same and the material realities (rivers) are sites of intense negotiation (e.g. The Center for Governmental Studies, 2002; Emery et al., 2013). City politics and discourses have direct material outcomes that can be understood through urban political economy, including the origins, roles and nature of environmental activism. In the Don River civic activism manifested in collective 'caring' for the river while the Los Angeles River first needed to establish its riparian reality and be 'discovered' by activists 
(Gumprecht, 1999; Desfor and Kiel, 2000; Orsi, 2004; Gandy, 2006; Wolch, 2007). Even now the future of the Los Angeles River depends on a schism between top-down master planning for enhancing flood capacity (which retains the 'threatening river' discourse), versus ecological, community-based activism and environmentalism, both of which are essentially 'expert' visions for the river (Gandy, 2006). The ecological activism is also socio-economically driven and raises questions of social and environmental justice in defining the role and reality of the river (Gumprecht, 1999; Orsi, 2004; Gandy, 2006; Wolch, 2007). This also raises the question of what is lost in either case by 'restoring' the river to an "environmental simulacrum" with claims to represent the public interest (Gandy, 2006).

In this type of analysis rivers are artefacts as much as they are 'natural' features. The reverse is also true, that the nature and role of the river affects the socio-political structures around it, and the two co-evolve. Through these landscapes, activists articulate concerns and so change the meaning and the reality of the river in the urban context. Recognition of the roles of various political actors, including civic environmentalists, within the hybrid system provides useful explanatory insights. It may also be seen as a way of initiating alternative and more effective forms of governance and management of these systems, which will in turn have different material outcomes (Karvonen, 2010, 2011; Karvonen and Yocom, 2011). In both the Don and Los Angeles River cases activists used the rivers to mobilize opinion and new ideas of urban design and fluvial reality (Desfor and Kiel, 2000). It is striking that some of the schemes for redesigning the Los Angeles River re-envision it as something quite different from its original semi-arid, shallow, 'wash'. Visioning images show abundant riparian vegetation surrounding an apparently perennially- flowing river which serves many purposes and has multiple meanings (City of Los Angeles, accessed April 2014); that is, a complex socio-natural reality.

\section{Socio-natures of river restoration}


The Los Angeles River, and the Highland Creek case with which I began, illustrate the extensive effects that stream design, rehabilitation and restoration have had, and are having, on contemporary river morphology (Pasternak, 2013). Intentionally designed rivers have not historically been a topic of geomorphic analysis and yet they are a significant part of fluvial landscapes and an important part of the functioning of those landscapes. Consequently, understanding the process by which rivers are chosen for projects and the process of design itself is an essential part of explaining river morphology. Where and why these interventions occur, in what way and with what knowledge and methods, clearly has direct effects on the resulting morphology, function and future of the river system.

It has been said often that river restoration is a socio-political and cultural process as much as a scientific one (e.g. Brierley and Fryirs, 2008). But saying this does not get us closer to showing the ways in which river morphology is affected by this, how this process actually works, or to explaining why rivers look as they do as the outcome of that process. If socio-political processes are important to hybrid socio-natures of rivers, then it is necessary to learn something of the way this works as a means to explaining varieties of fluvial form. One example comes directly from the science of river restoration and fluvial geomorphology in what amounts to a power struggle of competing knowledge claims for river restoration in the United States (Lave, 2009, 2012, 2014). One of the points to emerge from this analysis is that the political economy of stream restoration science has direct material effects on the appearance of river systems. For example, in the case of the Rosgen Natural Channel Design approach (Rosgen, 1996) and its wide adoption in the United States, Lave (2014) argues that this has the potential to homogenize normally diverse landscapes because a quasi-universal approach and methods are applied to large numbers of rivers and streams. It is necessary to understand why particular approaches may dominate and, borrowing from science and technology studies, Lave (2014) proposes that this is in part related to a 'sociology of expectation', an analysis of which is used to understand why some technological innovations survive and others do not. In particular, it provides a 
potential means to understanding the prevalence of Rosgen's ideas over those of others in particular contexts.

Legislative and political-economic processes are also at work to affect restoration practice, and the origins of extensive rehabilitation work in the United States can be traced back to the requirements of the Clean Water Act (James and Marcus, 2006; Lave, 2014), the application of which attempts to impose some federal-level uniformity but elements of which are variably applied locally (Doyle et al., 2013). In addition, it can be argued that the commercialization of the field has had significant effects in the final decisions about channel design (Pasternak, 2013; Lave, 2014). This includes the possibility that, for example, in a neo-liberal political climate, private and commercially-valuable knowledge claims may be "valorized" (Lave, 2014) and privileged over public and peer-reviewed academic knowledge. There are significant commercial interests at stake related to these knowledge claims that may inhibit modification of the methods and designs (Pasternak, 2013). If intensive and expensive projects are more profitable than low impact approaches then the former may prevail (Lave, 2014) with direct consequences for the fluvial landscape. Lave (2014) also argues that particular claims that rivers could be both 'natural' and stable led to the rise of the widespread stream restoration enterprise in the first place, in the absence of which these restored stream transformations may not have occurred at all.

The restoration industry can be viewed as re-designing rivers by re-imagining and reconfiguring the fluvial landscape according to a particular set of precepts and ambitions, the application of certain scientific conceptions, founded on a pre-determined 'need to restore', and in line with particular styles determined by vision, values, politics and the market. Tadaki et al. (2014b) make essentially this point with respect to the role of river classification systems in river management practices. One consequence is that these processes play out in different ways and with different consequences in different places, for reasons that are only partly related to the 
geomorphic characteristics of the region. This effect of differing socio-natural contingencies leading to different fluvial landscapes is also a theme in socio-hydrological studies (Di Baldassarre et al., 2014; Lane, 2014), and is susceptible to empirical, comparative analysis.

Consequently restoration outcomes can also be understood by detailed case analysis, viewing restoration itself as a socio-natural phenomenon (e.g. Eden et al., 2000; McDonald et al., 2004; Eden and Tunstall, 2006; Bracken and Oughton, 2013; Emery et al., 2013). Restoration is an intertwining of social, scientific, technical, and natural actors and both the river and the restoration project are transformed in the process. A close analysis of the context, motivation and development of a restoration project on the River Cole, England (Eden et al., 2000) showed how the specifics of the project were negotiated among various actors with varying interests, expertise, motivations and ideas of what the river used to be and what it ought to be. In this way it is possible to explain how the river came to be, within the limits of what was pragmatically possible and permissible in the specific context, as well as ways of framing and understanding the negotiated outcome (Bracken and Oughton, 2013). Although projects are local, they are also tied to global knowledge networks and norms that are translated into the local outcome. A single case is also part of a chain of ideas and transformations stimulated by larger projects such as European Union funding and agendas for riverscapes (Eden et al., 2000; McDonald et al., 2004). The larger socio-political framework, all the way down to local decision chains and negotiations, can be seen as part of the explanation of river characteristics.

\section{Intention and intervention in river morphology}

An important element of the socio-natures of rivers is that fluvial geomorphologists no longer stand apart from the system because geomorphology is directly applied to management, restoration and design of rivers. This alone disturbs the normal scientific view of objective 
scientists standing apart from the system that they are analyzing (Lane, 2014). There is wide discussion about the roles and methods by which geomorphologists may intervene, the importance of establishing generalised theory and scientific basis for restoration (Wohl et al., 2005; Bennett et al., 2011), and acknowledgement that outcomes are also driven by community goals and decisions (McDonald et al., 2004; Bennett et al., 2011; Pasternak, 2013). But seldom has the position, intention and the nature of the intervention of geomorphologists (and other actors) been explicitly considered such that we can see how geomorphology is integrated into the hybrid co-production of riverscapes in deciding locations, need and nature of such interventions or 'management' actions, and in analyzing and categorising river type and function (Tadaki et al., 2014b). This requires a substantial shift in stance and philosophy. Borrowing ideas from socio-hydrology (Lane, 2014) this includes recognition that geomorphologists are not experts outside the system but part of the system, that science is not linearly translated into outcomes, and that the ways in which geomorphologists conceive and model landscapes is not a neutral activity and may transform those landscapes as much as they represent them. Tadaki et al. (2014b) argue that the design and adoption of particular river classification schemes is part of this process which has an important role in framing management practices . Classification schemes are 'more-than-scientific' constructions that act on rivers in particular ways. Collateral material results for the riverscape will differ depending on the scheme adopted and its role and influence in the restoration process. In this way, classification activities and politics have direct outcomes for the river depending directly on geomorphological conceptions of rivers which are decision-making rationalities rather than strict 'truths of nature' (Tadaki et al., 2014b).

Bouleau (2013) argues from an analysis of the history of interventions and plans in the Rhône and Seine Rivers that particular scientific conceptions and representations of the rivers have direct material outcomes for the appearance and trajectory of the river morphology, 
environment and policy. Furthermore, these outcomes can be directly tied, in part, to the motivations of the scientists as actors in the co-production of the "waterscape" and their exploitation of the related scientific opportunities which differed between the two rivers. In the case of the upper Rhone, Bouleau (2013) concludes that the river became a site for ambitious scientists looking for interesting physical and human changes to observe and that the river was conceived and promoted, according to their own particular training and interests, as a linked hydro-system within which they could undertake further research. Geomorphic and ecological knowledge was privileged in conceptions of the river and what the river should look like. Envisaging the upper Rhône as a hydro-system with linked ecological and geomorphic function had direct consequences for (non)development of hydro power schemes, the management framework and goals, the maintenance of in-stream flows, the subsequent restoration narrative, and the river scape as a whole. The scientists saw the river they were (self?) interested in seeing and knowing and at the same time the river shaped the science through these opportunities to act and intervene, and therefore the future management paths and opportunities (Bouleau, 2013; Toone et al., 2014). Particular waterscapes do not interest all river scientists in the same way and this changes the river materially and conceptually (Bouleau, 2013). Therefore, particular disciplines or groups of scientists have a framing effect on the problems, and the solutions, with direct consequences for the river form, function and future (and see Tadaki et al., 2014b).

Critical examination of geomorphic conceptions of rivers is an important element of the explanation of morphology whether directly through river restoration or less directly through 'global' conceptions and knowledges of rivers more generally (Eden et al., 200o; McDonald et al., 2004). A consistent thread in the past two decades or more of river restoration research and practice is essentially one in which applied fluvial geomorphology is seen as a science for designing, managing, rehabilitating, restoring, repairing, sustaining, improving and conserving 
rivers (e.g. Wohl et al, 2005; Brierley and Fryirs, 2008; Bennett et al., 2011; Pasternak, 2013). This reveals a particular set of views of the river and geomorphic approaches for analysing rivers: machines in need of repair, damaged landscapes, impacted landscapes in need of 'renaturalising', contrasting to some extent with earlier engineering conceptions of command and control (Orsi, 2004) and Promethean projects (Karvonen, 2011). I do not mean to criticise or deny the validity and value of these views and restoration activities, or to suggest that they should not happen, but rather to point out, as Bouleau (2013) argues, that whatever is the view of the river from geomorphic intervenors and their associated scientific knowledge, it has material consequences for the river morphology. The role, function and motivation of geomorphologists in this socio-natural system, and the consequences for the system itself, have gone largely unexamined (but see Lave, 2009, 2014 and Tadaki et al., 2014a,b), along with reflection on the consequences of these actions (Lane, 2014). As has been argued by some biologists in the case of approaches to 'invasive' species (e.g. Chew, 2009), scientists may not be neutral participants and observers. There are important implications here for the way that geomorphologists see their role and knowledge, interact with others, and approach alternative 'ways of knowing' the landscape and this is something that needs greater attention in geomorphic research (see Tadaki et al., 2014a)

It should also be understood that, in the physical conception of the river, there are alternative visions, based in river dynamics, but building on principles that are not solely geomorphic. Prominksi et al. (2012) provide such an alternative set of conceptions for urban rivers, motivated in part by the European Water Framework Directive which has encouraged revitalisation of urban rivers. In this case, based in concepts from urban design and landscape architecture, they devised a typology of designs based partly on the nature of lateral and vertical constraints to the water and the channel. This typology has elements of flood hydrology and fluvial dynamics (e.g. in the vertical and lateral spread of water) familiar to fluviologists, but is 
motivated by conceptions of rivers as spaces for contemplation and recuperation where landscape aesthetics is important and riverscapes are enlivened and varied activity spaces. Thus, vertical fluctuations of water level are an aesthetic issue and a subject for design, rather than simply a hydraulic or hydrologic problem. An understanding of alternative conceptions of rivers, especially from the direction of explicit landscape design, may therefore be an important component in explaining river form in intentionally designed and restored rivers.

\section{Conclusion: moving on with sociogeomorphology}

Using several examples from the literature I have reviewed ways in which explicit development of a more socio-geomorphic approach can extend explanations of river morphology from those normally conceived in geomorphology. I have proposed the term sociogeomorphology to address the co-evolution of socio-natural systems and the analysis of human intention and action from social science perspectives. This framing distinguishes it from anthropogeomorphology, in which analysis tends to focus on (unexamined) human impact on a 'natural' system or on humans as emergent agents in a physical system whose role may be externalised to the extent of being a further phase in the evolution of the planet (Haff, 2010, 2012).

If rivers are seen as socio-natural co-productions, then a series of ideas follow about the ways in which these systems interact to produce river morphology. Differences in fluvial morphology can be observed and expected for socio-political reasons alone, but the key here is to understand this as part of a combined socio-natural system in which the river also affects the human elements of the system and in which history plays a role. I have identified some concrete examples of this that point to ways in which future analyses, 'experiments' (see Lane, 2014) and comparisons may be done in developing socio-geomorphic understanding of rivers. To paraphrase Hartmann (2011) in relation to floodplains, rivers are seen as situation- dependent poly-rationalities with plastic conceptions and social constructions of 'nature'. They also have 
complex, contingent local and general 'event' histories with specific consequences in particular places.

This also involves a commitment to the idea that 'highly-impacted', engineered and designed landscapes are important phenomena for geomorphic enquiry, especially in a world where human agency may be more important than 'natural' processes in shaping riverscapes and landforms.

Especially in cases in which geomorphic expertise is specifically part of the system, there is also a need for a change of ontological and epistemological positions (Urban, 2002; Linton and Budds, 2013; Lane, 2014) and a critical and reflexive stance related to intention and intervention, and to geomorphic knowledge more generally (Lane, 2014; Tadaki et al., 2014a,b). This is not something with which geomorphologists are normally familiar and comfortable, and some may disagree with this shift in philosophical position. Adopting this approach also involves moving towards acceptance of a broader conception of contingency, a critical analysis of local and global knowledge, the role and nature of generalized knowledge of river morphology, and a rethinking of the 'scientific nature' of geomorphology in these circumstances, along with a reformulation of the position of geomorphology with respect to the landscapes that are investigated.

Social scientists have much to offer in ideas and experience in undertaking this kind of work in which inter-disciplinary collaboration may be useful. There is also substantial recent research on the social science of environmental decision making, and framing of interdisciplinary research, that will be valuable for both theory and method in pursuing this type of geomorphology (Oughton and Bracken, 2009; Emery et al., 2013). But I propose that this is primarily a valid and necessary part of geomorphic enquiry, the development of which can and should happen within expanded conceptions of the scope and nature of geomorphology necessary for pursuing sociogeomorphology. The reward will be more complete understanding of both geomorphology 
and of the role and the consequences of geomorphologists' understanding of, and interventions in, these systems.

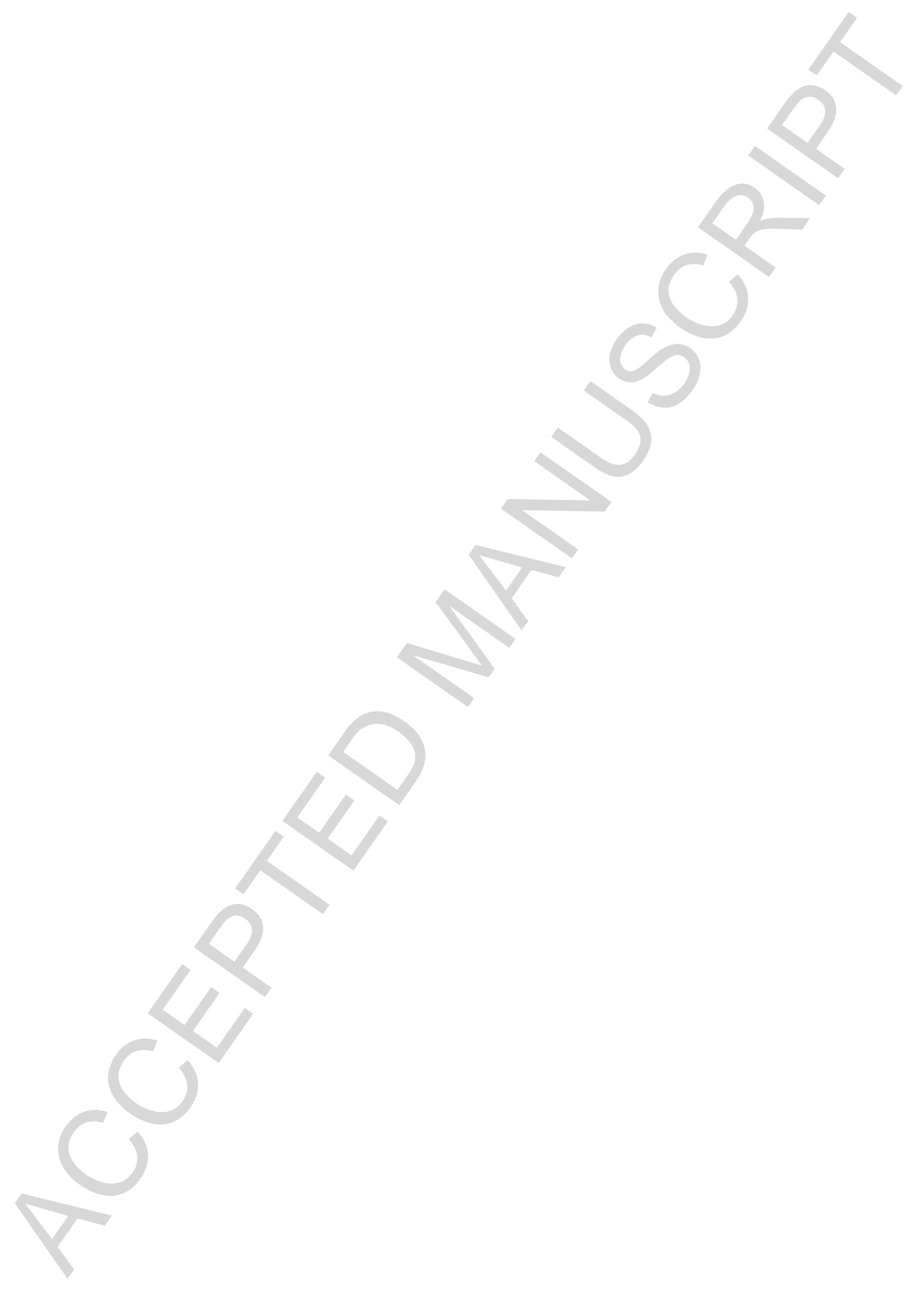




\section{Acknowledgments}

Some of the ideas in this paper originated with my encounters with urban rivers in Toronto that were initially funded by an NSERC Strategic Project Grant with Ray Kostaschuk (University of Guelph) and Joe Desloges (University of Toronto), and supported by City of Toronto, Toronto Region Conservation Authority, Parish Geomorphic and Aquafor Beech Ltd. Thesis research by Mariane Vocal-Ferencevic, John McDonald and Sarah O'Neill provided background on the Highland Creek case. The ideas in this paper are separate from these collaborations. I am grateful to Belinda Dodson who has encouraged me intellectually along this path, to Gary Brierley for his enthusiasm when he first heard me talk on this topic at the IAG conference in 2013, and to Gary Brierley and Janet Hooke for their invitation to submit to the Special Issue. I thank Marc Tadaki and an anonymous reviewer for their positive and thorough engagement in the paper, suggestions for revision and additional references. For Alick. 


\section{References}

Anderson, R.S., Anderson, S.P. 2010. Geomorphology: the mechanics and chemistry of landscapes. Cambridge, Cambridge University Press. 637 pp.

Bakker, K. 2009. Water. In: Castree, N., Demeritt, D., Liverman, D., Rhoads, B. (Eds) Companion to Environmental Geography. Blackwell, Oxford, 515-532.

Bennett, S.J., Simon, A., Castro, J.M., Atkinson, J.F., Bronner, C.E., Blersch, S.S., Rabideau, A.J., 2011. The evolving scince of stream restoration. In: Simon, A., Bennett, S.J. Castro, J.M. (Eds.), Stream Restoration in Dynamic Fluvial Systems: Scientific Approaches, Analyeses and Tools. American Geophysical Union, Washington D.C., Geophysical Monograph 194, pp. 1-8.

Bouleau, G. 2013. The co-production of science and waterscapes: The case of the Seine and the Rhône Rivers, France. Geoforum 57, 248-257.

Bracken, L.J., Oughton, E.A. 2013. Making sense of policy implementation: The construction and uses of expertise and evidence in managing freshwater environments. Environmental Science and Policy 30, 10-18.

Brierley, G., Fryirs, K.A. (Editors) 2008. River Futures: an integrative scientific approach to river repair. Society for Ecological Restoration International, Island Press, Washington, 304 pp.

Budds, J., Linton, J., McDonnell, R. 2014. The hydrosocial cycle. Geoforum 57, 167-169.

Castree, N. 2005. Nature. Routledge, Abingdon and New York. 281 pp.

Chew, M.K. 2009. The monstering of tamarisk: how scientists made a plant into a problem. Journal of the History of Biology 42, 231-266.

Chin, A. 2006. Urban transformation of river landscapes in a global context. Geomorphology 79, $460-487$.

Chin, A., O’Dowd, A.H., Gregory, K.J. 2013. Urbanization and river channels. In: Shroder, J.F. (Editor in Chief), Wohl, E. (Volume Editor), Treatise on Geomorphology, V.9, Fluvial Geomorphology, San Diego: Academic Press, 809-827.

Church, M. 1984. On experimental method in geomorphology. In: Burt, T.Walling, D. (Eds.), Catchment Experiments in Fluvial Geomorphology. Norwich: Geobooks, 563-580.

City of Los Angeles. http://www.lariver.org/index.htm. Online. Accessed April 2014. 
Cooke, R.U. 1984. Geomorphological Hazards in Los Angeles. George Allen \& Unwin, London, $206 \mathrm{pp}$.

Desfor, G., Keil, R. 2000. Every river tells a story: the Don River (Toronto) and the Los Angeles River (Los Angeles) as articulating landscapes. Journal of Environmental Policy and Planning 2, 5-23.

Di Baldassarre, G., Kooy, M., Kemerink, J.S., Brandimarte, L. 2013. Towards understanding the dynamic behaviour of floodplains as human-water systems. Hydrology and Earth System Science 17, 3235-3244. Douglas, I., Lawson, N. 2001. The human dimensions of geomorphological work in Britain. Journal of Industrial Ecology 4, 9-33.

Doyle, M. W., Lave, R., Robertson, M.M., Ferguson, J. 2013. River federalism. Annals of the American Association of Geographers 103, 290-298.

Eden, S., Tunstall, S. 2006. Ecological versus social restoration? How urban river restoration challenges but fails to challenge the science-policy nexus in the United Kingdom. Environment and Planning C: Government and Policy 24, 661-680.

Eden, S., Tunstall, S.M., Tapsell, S.M. 2000. Translating nature: river restoration as natureculture. Environment and Planning D: Society and Space 18, 257-273.

Emery, S.B., Perks, M.T., Bracken, L.J. 2013. Reframing environmental restoration: Evidence and persuasion in the truncation of an upland bend in the River Esk, UK. Geoforum 47, 167-177.

Ertsen, M.W., Murphy, J.T., Purdue, L.E., Zhu, T. 2014. A journey of a thousand miles begins with one small step - human agency, hydrological processes and time in socio-hydrology. Hydrology and Earth System Sciences 18, 1369-1382.

Gandy, M. 2006. Riparian anomie: Reflections on the Los Angeles River. Landscape Research $31,135-145$.

Graf, W. 1996. Geomorphology and policy for restoration of impounded American rivers: What is 'natural?'. In: Rhoads, B.L. and Thorn, C.E. (Eds.), The Scientific Nature of Geomorphology: Proceedings of the 27th Binghamton Symposium in Geomorphology. Wiley, New York, 443-473.

Gregory, K.J., 2000. The Changing Nature of Physical Geography. Chapter 10 Cultural physical geography. $2^{\text {nd }}$ Edition, Routledge, London, 254-271.

Gregory, K.J. 2006. The human role in changing river channels. Geomorphology 79, 172-191.

Gumprecht, B.1999. The Los Angeles River: Its Life, Death, and Possible Rebirth (Creating the North American Landscape). Johns Hopkins University Press, Baltimore, 384 pp.. 
Haff, P.K., 2002. Neogeomorphology. EOS 83, 310, 317.

Haff, P.K., 2003. Neogeomorphology, prediction and the Anthropic landscape. In: Wilcock, P.R., Iverson, R.M. Prediction in Geomorphology. Geophysical Monograph 135, American Geophysical Union, Washington, 15-26.

Haff, P.K. 2010. Hillslopes, rivers, plows, and trucks: mass transport on Earth's surface by natural and technological processes. Earth Surface Processes and Landforms 35, 1157-1166.

Haff, P.K., 2012. Technology and human purpose: the problem of solids transport on Earth's surface. Earth System Dynamics 3, 149-156.

Harden, C.P., Chin, A., English, M.R., Fu, R., Galvin, K.A., Gerlak, A.K., McDowell, P.F., McNamara, D.E., Peterson, J.M., Poff, N.L., Rosa, E.A., Solecki, W.D., Wohl, E.E. 2014. Understanding human-landscape interactions in the "Anthropocene”. Environmental Management 53, 4-13.

Hartmann, T. 2011. Clumsy floodplains: responsive land policy for extreme floods. Farnham, UK, Ashgate, $153 \mathrm{pp}$.

Hooke, R. LeB. 1994. On the efficacy of humans as geomorphic agents: GSA Today 4, 217, 224225 .

Hooke, R.LeB. 1999. Spatial distribution of human geomorphic activity in the United States: Earth Surface Processes and Landforms 24, 687-692.

Hulme, M. 2008. Geographical work at the boundaries of climate change. Transactions of the Institute of British Geographers 33:-11.

James, L.A., Marcus, A.W. 2006. The human role in changing fluvial systems: Retrospect, inventory and prospect. Geomorphology 79, 152-171.

Karvonen, A., 2010. Metronatural: Inventing and reworking urban nature in Seattle. Progress in Planning 74, 153-202.

Karvonen, A. 2011. Politics of Urban Runoff: Nature, Technology, and the Sustainable City. Urban and Industrial Environments Series. MIT Press, Cambridge MA and London,306 pp.

Karvonen, A., Yocom, K. 2011. The civics of urban nature: enacting hybrid landscapes.

Environment and Planning A 43, 1305-1322.

Kondolf, G. M. 2006. River restoration and meanders. Ecology and Society 11, 42. [online] URL: http://www.ecologyandsociety.org/vol11/iss2/art42/

Lane, S.N., 2014. Acting, predicting and intervening in a socio-hydrological world. Hydrology and Earth System Sciences 18, 927-952. 
Lave, R. 2009. The controversy over Natural Channel Design: Substantive explanations and potential avenues for resolution. Journal of the American Water Resources Association 45, 15191532.

Lave, R. 2012. Fields and Streams: Stream Restoration, Neoliberalism, and the Future of Environmental Science. University of Georgia Press, Athens, GA, 184 pp..

Lave, R., 2014. Freedom and constraint: Generative expectations in the US stream restoration field. Geoforum 52, 236-244.

Lave, R. Wilson, M.W., Barron, E.S., Biermann, C., Carey, M.A., Duvall, C.S., Johnson, L., Lane, K.M., McClintock, N., Munroe, D., Pain, R., Proctor, J., Rhoads, B.L., Robertson, M.M., Rossi, J., Sayre, N.F., Simon, G., Tadaki, M., Van Dyke, C. 2014. Intervention: Critical physical geography. Canadian Geographer 58, 1-10.

Linton, J., 2008. Is the hydrological cycle sustainable? A historical-geographical critique of a modern concept. Annals of the Association of American Geographers 98, 630-649.

Linton, J. 2010. What is water? The history of a modern abstraction. University of British Columbia Press, Vancouver, 333 pp.

Linton, J., Budds, J. 2014. The hydrosocial cycle: Defining and mobilizing a relationaldialectical approach to water. Geoforum $57,170-$ 180.http://dx.doi.org/10.1016/j.geoforum.2013.10.008

McDonald, A., Lane, S.N., Haycock, N.E., Chalk, E.A. 2004. Rivers of dreams: on the gulf between theoretical and practical aspects of an upland river restoration. Transactions of the Institute of British Geographers 29, 257-281.

McDonald, J. 2011. Response of river channel morphology to urbanization: the case of Highland Creek, Toronto, Ontario, 1954-2005. M.Sc. Thesis, TheUniversity of Western Ontario.

McLean, W. 2004. Paths to the living city: the story of the Toronto and Region Conservation Authority. Toronto Region Conservation Authority, Toronto, 251pp.

National Research Council, 2010. Landscapes on the Edge: New Horizons for Research on Earth's Surface. National Academies Press, Washington, D.C., 180 pp.

O’Neill, K. M. 2006. Rivers by Design: state power and the origins of U.S. flood control. Duke University Press, Durham, , 278pp.

O'Neill, S. 2008. Effects of Urbanization on Streamflow Regime in the Greater Toronto Area. B.Sc. Thesis, The University of Western Ontario.

Orsi, J. 2004. Hazardous Metropolis: Flooding and urban ecology in Los Angeles. University of California Press, Berkeley, 276 pp. 
Oughton, E.A., Bracken, L.J. 2009. Framing interdisciplinary research. Area 41, 385-394

Overeem, I. , Kettner, A.J., Syvitski,J. 2013. Impacts of humans on river fluxes and morphology. In Wohl, E. (ed.), Treatise of Geomorphology: Volume 9, Fluvial Geomorphology. Elsevier, New York, 828-842.

Pasternak, G. B. 2013. Geomorphologist's guide to participating in river rehabilitation. In: Shroder, J.F. (Editor in Chief), Wohl, E. (Volume Editor), Treatise on Geomorphology, V.9, Fluvial Geomorphology, San Diego: Academic Press, 843-86o.

Price, S.J., Ford, J.R., Cooper, A.H., Neal, C. 2011. Humans as major geological and geomorphological agents in the Anthropocene: the significance of artificial ground in Great Britain. Philosophical Transactions of the Royal Society A 369, 1056-1084.

Pritchard, S.B. 2011. Confluence: the nature of technology and the remaking of the Rhone. Harvard University Press, Cambridge, 371pp.

Prominski, M., Stokman, A., Stimberg, D., Voermanek, H., Zeller, S. 2012. River.Space.Design: Planning Strategies, Methods and Projects for Urban Streams. Birkhäuser, De Greuter, Basel, $256 \mathrm{pp}$.

Rosgen, D., 1996. Applied River Morphology. Fort Collins Colorado, Wildland Hydrology.

Satgunarajah, A. 2009. Determination of imperviousness in the Highland Creek catchment. Studies by Undergraduate Researchers at Guelph 3, 26-30.

Sivapalan, M., Savenije, H. H. G., Blöschl, G. 2011. Socio-hydrology: a new science of people and water. Hydrological Processes, 26, 1270-1276.

Slaymaker, O., 2009. The future of geomorphology. Geography Compass, 3, 329-349

Szabo, J., David, L., Loczy, D (editors) 2010. Anthropogenic Geomorphology. Dordrecht : Springer Science+Business Media B.V. Online e-book. 298 pp.

Tadaki, M., Brierley, G., Dickson, M., Le Heron, R., Salmond, J., 2014a. Cultivating critical practices in physical geography. The Geographical Journal 10.1111/geoj.12082.

Tadaki, M. , Brierley, G. and Cullum, C. 2014b. River classification: theory, practice, politics. WIREs Water, 1, 349-367.

The Center for Governmental Studies, 2002. Alluvial Amnesia: how officials imperil communities by downplaying flood risks. http://www.unz.org/Pub/CGS Report2002?View=PDF 
Toone, J., Rice, S.P, Peigay, H., 2014. Spatial discontinuity and temporal evolution of channel morphology along a mixed bedrock-alluvial river, upper Drôme River, southeast France: Contingent responses to external and internal controls. Geomorphology 205, 5-16.

Toronto Region Conservation Authority (TRCA) and City of Toronto. (1999). State of the Watershed Report: Highland Creek Catchment, Toronto, 17op.

http://trca.on.ca/dotAsset/91720.pdf accessed April 2014.

Urban, M., 2002. Conceptualizing anthropogenic change in fluvial systems: drainage development on the Upper Embarras River, Illinois. Professional Geographer, 54, 204-217.

Vocal-Ferencevic, M., Ashmore, P. 2012. Creating and evaluating DEM-based stream power maps as a stream assessment tool. River Research and Applications 28, 1394-1416.

Waley, P., Åberg, E.U. 2011. Finding spaces for flowing water in Japan's densely populated landscapes. Environment and Planning A 43, 2321-2336.

Wilcock, D., Brierley, G., Howitt, R., 2013. Ethnogeomorphology. Progress in Physical Geography 37, 573-600.

Winiwarter, V., Schmid, M., Dressel, G. 2013 Looking at half a millennium of co-existence: the Danube in Vienna as a socio-natural site. Water History 5, 101-119.

Wohl, E., Angermaier, P.L., Bledsoe, B., Kondolf, G.M., MacDonnell, L., Merritt, D.M., Palmer, M.A., Poff, N.L., Tarboton, D., 2005. River restoration. Water Resources Research 41 W10301, doi:10-1029/2005WRo03985.

Wohl, E., Gerlak, A.K., Poff, N.L., Chin, A. 2014. Common core themes in geomorphic, ecological and social systems. Environmental Management 53, 12-27.

Wolch, J. 2007. Green urban worlds. Annals of the Association of American Geographers 97, 373-384. 
Highlights

- A sociogeomorphic approach to river morphology is proposed

- The approach is distinct from previous anthropo-geomorphic conceptions of 'human impact' on nature

- Rivers (and other landforms) are seen as co-produced socio-natures

- Cultural and socio-political events, agency and local contingency may be directly part of explanations of river form

- Geomorphology(ists) are part of socio-nature, especially for designed and managed rivers

- Pursuit of this approach will involve reflexivity and alternative approaches to geomorphological knowledge 